\title{
Sustainability Assessment of Wastewater Systems: An Environmental and Economic Approach
}

\author{
Alejandro Padilla-Rivera*, Juan Manuel Morgan-Sagastume, \\ Leonor Patricia Güereca-Hernández \\ Instituto de Ingeniería, Universidad Nacional Autónoma de México, Coyoacán, Mexico City, Mexico \\ Email: *apadillar@iingen.unam.mx
}

How to cite this paper: Padilla-Rivera, A. Morgan-Sagastume, J.M. and GüerecaHernández, L.P. (2019) Sustainability Assessment of Wastewater Systems: An Environmental and Economic Approach. Journal of Environmental Protection, 10, 241259 .

https://doi.org/10.4236/jep.2019.102014

Received: October 11, 2018

Accepted: February 10, 2019

Published: February 13, 2019

Copyright $\odot 2019$ by author(s) and Scientific Research Publishing Inc. This work is licensed under the Creative Commons Attribution International License (CC BY 4.0).

http://creativecommons.org/licenses/by/4.0/

\begin{abstract}
To address current challenges regarding sustainable development of wastewater treatment and provide scientific support in decision procedures towards sustainable solutions, new approaches, frameworks and methodologies about different possible solutions and their potential sustainability implications are needed. One way to facilitate sustainability assessment of wastewater is Life Cycle Assessment (LCA) methodology; however, it fails to map the full scope of wastewater impacts. This paper presents a framework to evaluate the performance of Wastewater Treatment Facilities (WWTF) taking into consideration various factors for insuring environmental sustainability. A total of nine indicators, seven environmental and two economic related to four wastewater treatment facilities, were assessed. Apart from evaluating the sustainability, this study also discussed the link of life cycle approach and social aspects of wastewater. The results show that for the environmental dimension using LCA provides information on different types of environmental activities and different impact categories. LCA can thus be used to quantify and compare the multiple types of impacts caused by one type of use or emission, as well as the various resource uses or emissions that contribute to one type of impacts. For the economic dimension, there is still a need for consistent and robust indicators and methods. The empirical results suggest that the environmental sustainability framework can be used in the first phase of the decision procedure that leads to a strategic choice for sustainable resource recovery from wastewater in developing countries. This motives researchers and decision-makers to consider the whole picture, and not just individual aspects, when considering different futures scenarios.
\end{abstract}

\section{Keywords}

Environmental life Cycle Assessment, Wastewater Treatment, Economic Costs 


\section{Introduction}

Nowadays, a solid comprehensive sustainability assessment approach is essential in the water and wastewater processes. In the last century, sustainability of wastewater has emerged in many different approaches all over the world, and has become a standard practice in developed nations and a key inspiration in developing countries [1]. The term sustainability describes development "that meets the needs of the present without compromising the ability of future generations to meet their own needs" [2] while the term sustainability assessment can be used to refer to "processes that are ex post evaluate techniques as well as those that are forward-looking ex ante processes that aim to predict the potential effects of an activity prior to its implementation" [3]. The null universal consensus of these terms and a single way for conducting them are still very limited.

Over the last decades many methods and tools for environmental and sustainability performance have emerged. One of them is life cycle thinking, which represents the basic concept of the whole product system life cycle from cradle to grave. Although life cycle thinking is a qualitative approach, it has been represented by Life Cycle Assessment (LCA), built around the principle of comprehensiveness and therefore it aims to address all environmental interventions. The LCA has been recognized as robust and holist framework for assessing environmental dimensions of sustainability. However, LCA focus on environmental aspects misses the social and economic dimension of sustainability. One form of sustainability assessment over the life cycle is life cycle sustainability assessment [4] comparison the three pillars of sustainability, environment, economy and society. However, the maturity of methodologies and tools, under life cycle framework, is different for three sustainability dimensions [5]. Whereas the environmental dimension is well covered by Environmental Life Cycle Assessment [6]; the economic and social pillars still require fundamental scientific progress. This broad view of sustainability assessment brings with it some additional challenges for both researchers and practitioners, not the least of which is how to make sense of the range of applications, processes and practices that now proliferate [3].

Various studies have been done to solve sustainability assessment related to wastewater issues considering different criteria, through the use of multi-criteria decision analysis [7] [8] [9], the implementation of integer programming conducted by choosing sustainable wastewater treatment systems [10] or applied techniques for order preference by similarity to ideal solutions method to rank wastewater technologies [11]. All of these studies considered, environmental and economic aspects of each technology, but they have prioritized the selection based on their cost, nonetheless LCA was not performed.

Regarding to the sustainability performance of wastewater treatment plants, the integrated sustainability assessment method based on life cycle thinking is highly necessary for selecting the best sustainable technology by considering economic, technological, environmental and social aspects. In this situation, 
and, according to Pahl-Wostl et al. [12], few studies have taken an integrated and holistic approach related to wastewater treatment plants and sustainability with the full incorporation of all the components defined in literature; economic, social and environmental issues through the life cycle approach. These issues must be addressed in indicators that should integrate concerns about the supply, distribution, quality, environmental and social impacts of wastewater, in order to minimize the negative impact on receiving bodies, ecosystems, agricultural production and society.

To enhance sustainability in wastewater management, public policies must be based in holistic information, supporting the social wellbeing of the population, the maintenance of processes and environmental services and the governance principles. This implies the importance of evaluating the policy, social and economic effects in addition to environmental impact studies [13] [14] [15].

Thus far, the focus on LCAs of wastewater treatment systems has not integrated social nor economic aspects in life cycle approach, but rather than on environmental assessment of wastewater treatment plants [16]. Furthermore, most of the studies that evaluate the sustainability of wastewater have a geographical scope outside of the México [17] [18] [19], focus solely on economic indicators [20] [21] or environmental indicators [18] [22]. To the knowledge of the authors, no environmental sustainability evaluation of onsite wastewater treatment systems has been conducted with reference to considered life cycle thinking in Mexico. To reflect all dimensions of sustainability, this paper focuses on the operation of Wastewater Treatment Facilities (WWTF).

The paper presents an eco-efficiency approach by evaluating the environmental and economic aspects of wastewater treatment facilities to select the most appropriate in terms of water sustainability. Moreover, our aim is to help the public sector gain a better understanding of their improvements and vulnerabilities in the sanitation sector. The framework was applied to four WWTFs in two countries: in Los Angeles Metropolitan Area and Phoenix, in the United States; and in Metropolitan Mexico City (MMC), in México. In this case, we evaluated two facilities in the MMC. These areas face similar challenges in terms of population, economic importance and rapid urban development over relatively short periods.

\section{Methodological Approach}

In the present study, a multi-decision framework was proposed for selecting the most sustainable wastewater treatment facility in three cities under a life cycle approach as shown in Figure 1. This framework comprises three main steps: 1) environmental evaluation, 2) economic assessment and 3) articulation of environmental LCA and social indicators, each dimension evaluated independently. In addition, a summary table and a figure are presented to visualize the full image of sustainability (economic and environmental dimensions).

The evaluation took into consideration 9 indicators, which, seven of them are, environmental indicators (Abiotic Depletion, AD (Fossil Fuels MJ); Acidification, 


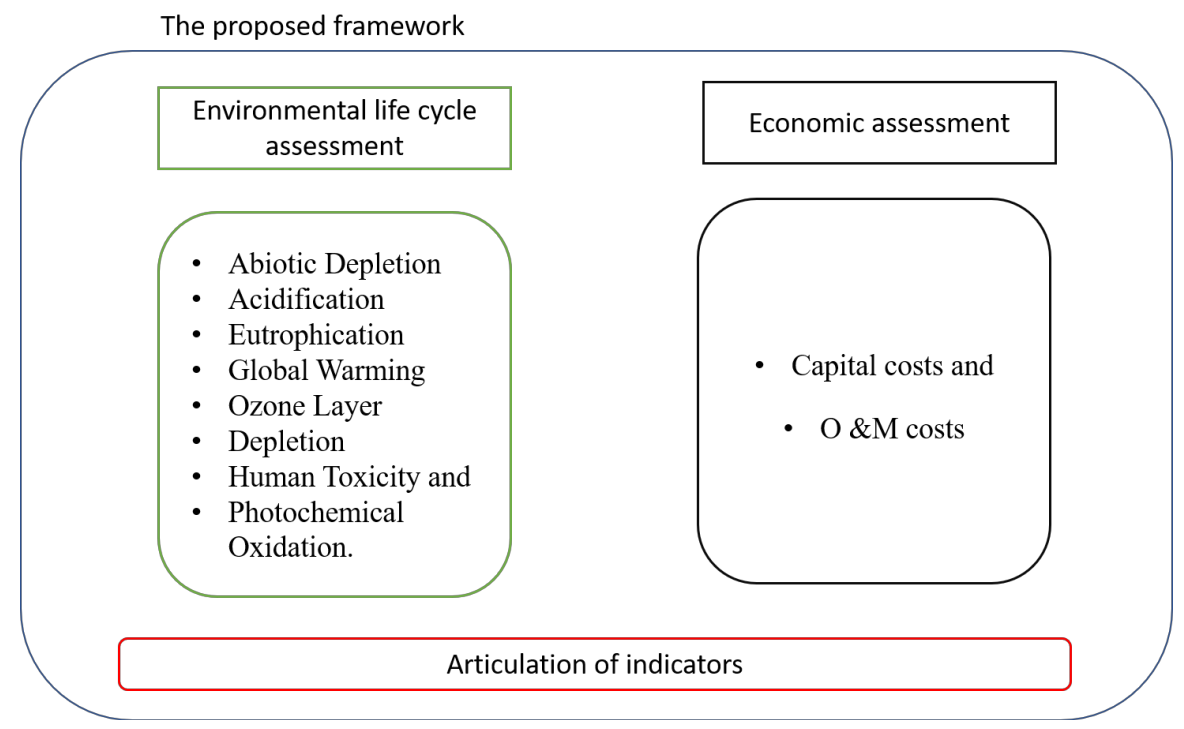

Figure 1. Indicators selected.

$\mathrm{AI}\left(\mathrm{g} \cdot \mathrm{SO}_{2} \cdot \mathrm{eq}\right)$; Eutrophication, EI (g.PO $\left.\mathrm{P}_{4} \cdot \mathrm{eq}\right)$; Global Warming, $\mathrm{GW}\left(\mathrm{g} \cdot \mathrm{CO}_{2} \cdot \mathrm{eq}\right)$; Ozone Layer Depletion, ODI (g.CFC- ${ }_{11} \cdot$ eq); Human Toxicity, HTI (g.1,4-DB·eq) and Photochemical Oxidation, POI) and two economic indicators (capital costs and Operation and Management (O \& M) costs).

\subsection{Environmental LCA}

\subsubsection{Life Cycle Assessment Methodology}

LCA is an assessment tool that aims at analyzing the environmental effects associated with a product, process or single activity over the entire course of its life or duration, i.e., from cradle to grave. The International Organization for Standardization (ISO) has published procedures for conducting LCA [6], which provide specific guidelines. LCA consists of four steps: the definition of goal and scope, the development of life cycle inventories, impact assessment, and interpretation. LCA is an iterative process in which the goal and scope are constantly adjusted depending on the data collection limitations and the insights provided by the impact assessment (Bauman and Tillman, 2004). The term "environmental impact" is used in LCA to refer to the effects of the studied system on the environment. These impacts depend directly on the evaluation method used during the impact assessment step. Such assessments are based on the development of a system model that quantifies the inputs (consumption of energy and materials) and outputs (emissions and wastes) released to the environment throughout the entire life cycle of the system. In this study, the ISO 14040 guidelines were applied to assess the environmental effects of wood pellet production from a cradle-to-gate perspective.

\subsubsection{Description of the Case Study}

The four WWTP analyzed and their characteristics are presented in Table 1 and the each one of the life cycle systems are presented in Figure 2. The functional 
Table 1. Descriptions and names of unit process considered in the life cycle impact assessment under study.

\begin{tabular}{cccccc}
\hline WWT & Abbreviation & Location & Technology & $\begin{array}{c}\text { Flow range } \\
\text { (operation) }\end{array}$ & $\begin{array}{c}\text { Treated water used } \\
\text { and sludge disposal }\end{array}$ \\
\hline Parque Naucalli & $\mathrm{Na}$ & Mexico City & Activated sludge. Aerated extention. & $22 \mathrm{~L} / \mathrm{s}$ & $\begin{array}{c}\text { Waterbody discharge, } \\
\text { no sludge treatment. }\end{array}$ \\
Phoenix & $\mathrm{Ph}$ & Arizona & Activated sludge. Completely mixed. & $1400 \mathrm{~L} / \mathrm{s}$ & $\begin{array}{c}\text { Waterbody discharge, anaerobic } \\
\text { digestion and fertilized. }\end{array}$ \\
Los Angeles & $\mathrm{La}$ & California & Activated sludge. Completely mixed. & $3000 \mathrm{~L} / \mathrm{s}$ & $\begin{array}{c}\text { Waterbody discharge, anaerobic } \\
\text { digestion and fertilized. } \\
\text { Water body discharge and urban } \\
\text { Iztapalapa }\end{array}$ \\
& $\mathrm{Iz}$ & Mexico City & Activated sludge. Completely mixed. & $1500 \mathrm{~L} / \mathrm{s}$ & $\begin{array}{c}\text { no sludge treatment. } \\
\text { reuse, }\end{array}$
\end{tabular}

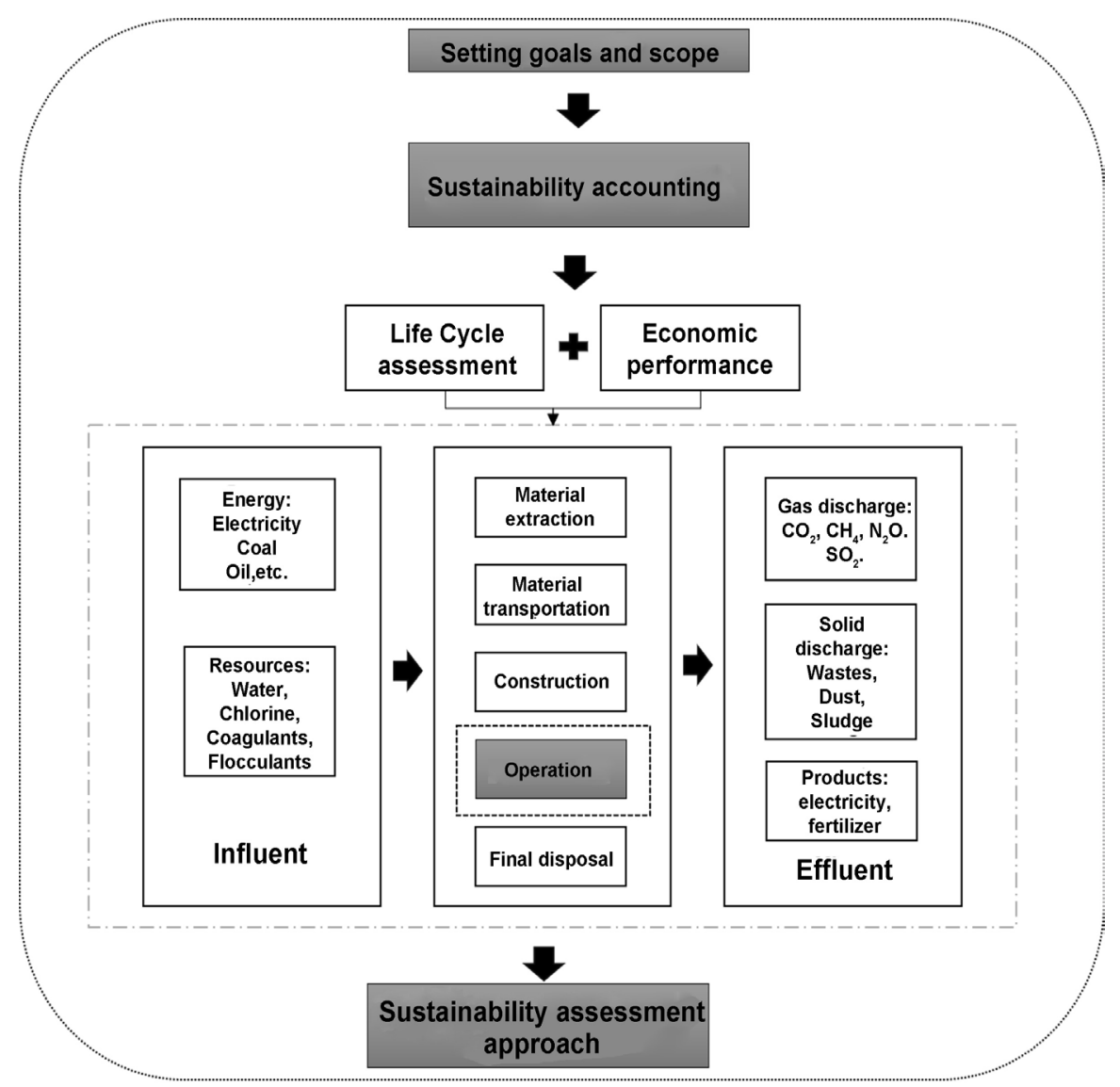

Figure 2. Framework used to evaluate the WWTF.

unit (comparison base), was defined as one cubic meter of treated water $\left(1 \mathrm{~m}^{3}\right)$. The wastewater treatment technologies selected (actitation sludge and derivate) are the most representative (80\%) among wastewater technologies according to Noyola et al. [23].

\subsubsection{System Boundary Description}

The system boundaries should include raw material extraction, production of materials and components, operation of the treatment plants as well as disposal and recycling of waste products. However, as Lundie et al. [24] and Lassaux et al. 
[25] have reported, the impact of the operation phase is larger than that of the construction stage. In addition, Tillman et al. [26] found that the investment impacts were similar for their different alternatives in contrast to those related to the operation of the treatment systems. Bearing all these in mind, the analysis presented here was limited to the operation stage of the WWTP and no considerations were given to the building and dismantling phases.

Figure 3 presents the system boundary for the gate-to-gate wastewater treatment operations of each facility based on the functional unit described above. The facilities under evaluation were divided into four main systems and one subsystem (sludge management). The wastewater production boundaries cover gate-to-gate emissions, energy, fuels and materials necessary to meet the production system requirements. The systems included in the wastewater treatment facilities were as follows: input of raw water, secondary treatment, tertiary treatment and water disposal.

\subsubsection{Life Cycle Inventory Analysis}

In the Life Cycle Inventory (LCI), data concerning energy use, resource use, as well as emissions to air and water, were collected for each of the flows that were considered to be relevant. Data was mainly collected from suppliers of treatment facilities, scientific articles, evaluation reports and information from national statistics. The LCI is presented in Table 2. We assumed a representative electricity mix for the Mexico sites, according to World Bank [27] and for the states of California and Arizona from Stokes and Horvath [28].

The selection of impact categories are based on two reviews performed by [16] [29] were the most used impact categories analyzed were: Abiotic Depletion, AD (Fossil Fuels MJ); Acidification, AI (g. $\left.\mathrm{SO}_{2} \cdot \mathrm{eq}\right)$; Eutrophication, EI (g.PO $\left.{ }_{4} \cdot \mathrm{eq}\right)$; Global Warming, GW (g. $\left.\mathrm{CO}_{2} \cdot \mathrm{eq}\right)$; Ozone Layer Depletion, ODI (g.CFC- $\left.{ }_{11} \cdot \mathrm{eq}\right)$; Human Toxicity, HTI (g.1,4-DB.eq) and Photochemical Oxidation, POI $\left(\mathrm{g} \cdot \mathrm{C}_{2} \mathrm{H}_{4}\right)$.

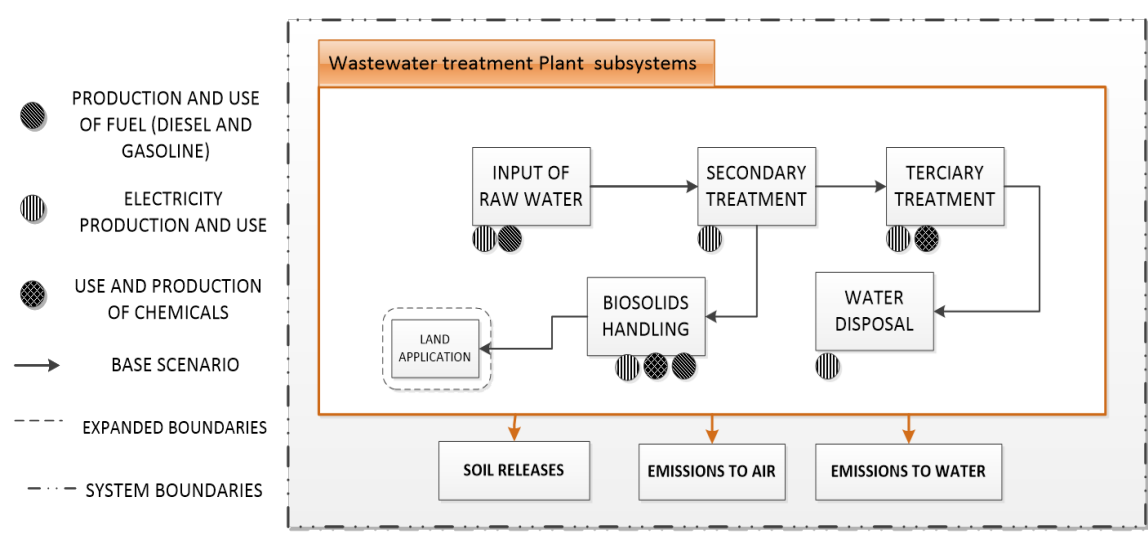

Figure 3. A detailed, schematic diagram of the facilities analyzed. For $\mathrm{Na}$ and Iz no Biosolids handling is considered. In activated sludge ${ }^{\star}$ correspond to Extended aeration and ${ }^{*}$ to traditional aeration. In Chlorine ${ }^{\star}$ correspond to liquid and ${ }^{\star *}$ to gas. 
Table 2. Life cycle inventory details.

\begin{tabular}{|c|c|c|c|c|}
\hline $\begin{array}{c}\text { Parameter } \\
\text { (per } 1 \mathrm{~m}^{3} \text { of treated water) }\end{array}$ & $\begin{array}{l}\text { WWTP1 } \\
\mathrm{Na}\end{array}$ & $\begin{array}{c}\text { WWTP2 } \\
\text { La }\end{array}$ & $\begin{array}{c}\text { WWTP3 } \\
\text { Ph }\end{array}$ & $\begin{array}{c}\text { WWTP4 } \\
\text { Iz }\end{array}$ \\
\hline \multicolumn{5}{|c|}{ Inputs } \\
\hline Total electricity $(\mathrm{kWh})^{1}$ & 2.13 & 0.4454 & 0.811 & 0.615 \\
\hline Chlorine $(\mathrm{kg})^{1}$ & 0.1263 & $2.15 \mathrm{E}-02$ & .0060 & 0.0869 \\
\hline Polymer $(\mathrm{kg})^{1}$ & --- & 0.02204 & 0.3590 & --- \\
\hline Truck use (tkm) & 0.00068 & 0.0245 & 1.057 & 0.0035 \\
\hline \multicolumn{5}{|c|}{ Outputs } \\
\hline Energy recovery (kWh) & --- & 0.42 & --- & --- \\
\hline \multicolumn{5}{|c|}{ Avoided impacts } \\
\hline $\mathrm{P}$ as fertilizer avoided $(\mathrm{kg})$ & --- & 0.06459 & 0.0305 & --- \\
\hline \multicolumn{5}{|c|}{ Emissions to water $(\mathrm{kg})$} \\
\hline Biochemical oxygen demand & 0.048 & 0.0153 & 0.002 & 0.00465 \\
\hline Chemical oxygen demand & 0.025 & 0.02 & 0.02 & 0.04034 \\
\hline Total suspend solids & 0.014 & 0.018 & 0.003 & 0.00811 \\
\hline Total nitrogen & 0.028 & 0.01 & 0.00235 & 0.00546 \\
\hline Total phosphorus & 0.0067 & 0.001 & 0.0026 & 0.004955 \\
\hline $\mathrm{Mn}$ & 0.00019 & 0.00035 & 0.00035 & 0.0000427 \\
\hline $\mathrm{Cu}$ & 0.000488 & 0.000043 & 0.000043 & 0.00026 \\
\hline $\mathrm{Fe}$ & 0.00076 & 0.00013 & 0.00013 & 0.0001455 \\
\hline $\mathrm{Pb}$ & 0.00082 & 0.00073 & 0.00073 & 0.0000689 \\
\hline $\mathrm{Zn}$ & 0.0000557 & 0.000081 & 0.000081 & 0.0000325 \\
\hline \multicolumn{5}{|c|}{ Emissions to soil $(\mathrm{kg})$} \\
\hline Sludge (dry matter) & 0.068 & 0.1293 & 5.28 & 0.0043 \\
\hline $\mathrm{Cd}$ & $5.80 \mathrm{E}-06$ & 0.000085 & 0.000085 & \\
\hline As & $5.12 \mathrm{E}-06$ & 0.000075 & 0.000075 & $3.27 \mathrm{E}-07$ \\
\hline $\mathrm{Cu}$ & 0.000293 & 0.00043 & 0.00043 & $3.71 \mathrm{E}-07$ \\
\hline $\mathrm{Hg}$ & $3.89 \mathrm{E}-06$ & 0.000057 & 0.000057 & $2.94 \mathrm{E}-07$ \\
\hline $\mathrm{Ni}$ & $2.86 \mathrm{E}-05$ & 0.00042 & 0.00042 & $1.83 \mathrm{E}-06$ \\
\hline $\mathrm{Pb}$ & $5.73 \mathrm{E}-05$ & 0.00084 & 0.00084 & $3.67 \mathrm{E}-06$ \\
\hline $\mathrm{Zn}$ & 0.0005123 & 0.0075 & 0.0075 & $3.27 \mathrm{E}-05$ \\
\hline \multicolumn{5}{|c|}{ Emissions to air } \\
\hline $\begin{array}{c}\text { Biogas produced in anaerobic } \\
\text { digestion }\left(\mathrm{m}^{3}\right)\end{array}$ & --- & $2.054 \mathrm{E}-06$ & 0.1251 & --- \\
\hline
\end{tabular}

CML IO Baseline V3.01 was the method utilized. The environmental assessment was performed with the support of the software SimaPro 8.02 and Ecoinvent $\mathrm{v} 3$ database [30].

\subsection{Selection of Study Areas}

We selected three large metropolises with wide areas to evaluate four different wastewater treatment facilities. The city selection was based on a comprehensive 
qualitative recognition for population, economy, climate and urbanization places identified by [31]. These cities present a connection between vegetation degradation and urbanization among 17 cities of North America and 50 large metropolises around the world and. By this extraction: Los Angeles, Phoenix and Mexico City were chosen for the case study, their selection among the 17 was mainly done by the accessibility to data source, access to installations and research goals by the authors.

\subsection{Economic Assessment}

The life cycle costing (LCC), the economic branch of life cycle methodology, assesses all costs associated with the life cycle of a product that are directly covered by one or more of the actors in the product life cycle [32].

Considering all costs in the sustainability assessment of the project is undoubtedly the appropriate practice to support the selection of the process, since the actual cost, in this case per cubic meter of treated water $\left(1 \mathrm{~m}^{3}\right)$, is determined. This involves not only the capital amounts required, but also the costs of operation and maintenance (O\&M) over the life of the plant to be built.

The evaluation of this type of indicators helps to characterize the behavior of wastewater treatment facilities (WWTF) in environmental and economic terms [33]; therefore, it helps to prioritize interventions in a context of sustainable decision making.

In this study, we determined the costs from the perspective of the actor, in this case the WWTP. As the systems under study were located in Mexico and USA, the currency selected was the American dollars (\$), and the costs assumed were valid for the 2017 year. Both indicators were chosen according to Noyola et al. [23].

To evaluate the economic assessment of WWTF only the capital and O\&M costs (internal costs) were included within the system boundaries. According, the following economic indicators referring to internal cost were selected:

- The capital cost represents the initial investment of all the facilities for WT processes, [34] pointed out that the capital cost has significant influence on the implementation of the projects about the WT, because the initial investment cost can significantly influence the decision-makers. The capital costs: were divided into the costs for piping, equipment (pump and motor), pump pits, construction expenses, and the contractor's overhead and profits.

- The O\&M cost included the costs of electricity, labor, and Maintenance and Repair (M\&R). The electricity cost was required for pumping, as well as wastewater treatment, such as the operation of agitators, flocculators and sludge scrapers and maintenance and repairs of machines. The labor cost consisted of operators' wages, as well as their expenses and overheads. The cost in the disposal stage was divided into the costs for recycling, landfill and construction expenses, as well as the contractor's overhead and profits. The M\&R cost was assumed to be $3 \%$ of a construction cost [35]. The costs were 
estimated in detail using databases containing price and cost information (internal reports).

\section{Results and Discussions}

\subsection{Environmental Life Cycle Assessment}

The potential environmental impact evaluated for each of the systems analyzed were indexed using the most contributor facility in each impact category as baseline according to data in Figure 3, where can be noted that Naucalpan utility presents higher impacts for $\mathrm{AD}, \mathrm{AI}$ and HTI, Arizona presents more contributions to GW and POI, Mexico in EU and ODP, while California doesn't present any high impact. The most environmental impacts of the four facilities are generated by the consumption electricity and quality water disposal. Total energy is for the systems (pumping, aeration, etc.)

\subsubsection{Acidification}

Emissions link to acidification are mainly caused by the production of the electricity used in each WWTP. From smaller to higher impact $\left(\mathrm{kg} \cdot \mathrm{SO}_{2} \cdot \mathrm{eq}\right)$ : -0.000579 in Los Angeles, 0.00407 in Iztapalapa, 0.004868 in Phoenix and 0.0109 in Naucalpan. These differences are due to the higher use of electricity in the facility of Naucalpan $\left(2.1 \mathrm{kWh} / \mathrm{m}^{3}\right)$, five more times than the lowest $0.44 \mathrm{kWh} / \mathrm{m}^{3}$ in Los Angeles. Nevertheless, these values cannot be compared with those available in literature, likely because of a functional unit factor scale. These results agree with Hospido et al. [36] in which they emphasize that the higher amount of water treatment in the facilities has the lower consumption of electricity per functional unit.

\subsubsection{Abiotic Depletion (Fossil Fuels)}

Depletion of abiotic resources was evaluated using the baseline method described by CML impact assessment method, which is based on ultimate reserves and extraction rates. Results are expressed as fossil fuels consumed given in MJ equivalents per $1 \mathrm{~m}^{3}$, as shown in Figure 4 .

Naucalpan facility generates the highest impact (16.36 MJ), followed by Iztapalapa (5.03 MJ) and Phoenix (7.25 MJ), while Los Angeles produces 0.366 MJ. These values are due to the production of electricity used and the avoided impacts by the manufacture of fertilizers balance effects of the WWTP of this impact category. If this process is disregarded for example in California facility, the comparison is dominated by the avoided burdens associated with the use of sludge as fertilizer in the Biosolids handling system. In the case of case of Naucalpan, Phoenix and Iztapalapa the results show that depletion of fossil resources dominates this impact category in the rest of the facilities.

\subsubsection{Global Warming}

The results from global warming, with a time horizon of 100 years, agree with the patterns observed in the other impact categories. The global warming impact 


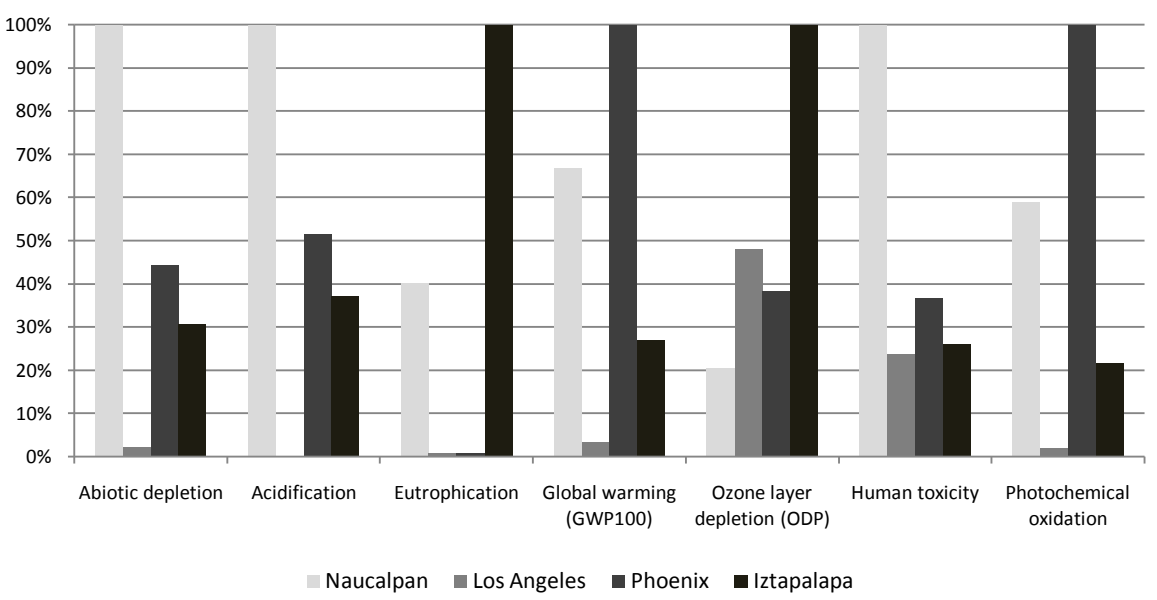

Figure 4. Characterized environmental impacts of the four systems analyzed.

is higher for Phoenix (2.21 kg. $\left.\mathrm{CO}_{2} \cdot \mathrm{eq}\right)$, followed by Naucalpan $\left(1.47 \mathrm{~kg} \cdot \mathrm{CO}_{2} \cdot \mathrm{eq}\right)$, then Iztapalapa $\left(0.60 \mathrm{~kg} \cdot \mathrm{CO}_{2}\right.$.eq and the lower impacts are showed by Los Angeles $\left(0.073 \mathrm{~kg} \cdot \mathrm{CO}_{2} \cdot \mathrm{eq}\right)$. Although this impact can be associated to the high use of electricity, in this case the high impact for GW is presented in the subsystem of biosolids handling due to biogas produced in the anaerobic digestion with no electricity recovery.

Regarding electricity mix, natural gas is used as the primary source of energy in the facilities, accounting for $55 \%, 35 \%$ and $48 \%$ of the mix in WWTP Los Angeles, WWTP Phoenix and WWTP Naucalpan and Iztapalapa respectively. This is a factor that determines the measure of global warming potential, so greenhouse emissions can directly be related to the energy mix used in this assessment.

A detailed analysis was carried to identify the subsystems that contribute most to the global warming impact. In WWTP Naucalpan, the secondary treatment and sludge handling account for more than $50 \%$ of the total value of the impact category. The greenhouse gas emissions are directly related to the energy consumption. The activated sludge system, as expected, presented the highest environmental burden in the global warming category, when compared to the other subsystems, due to the high energy input for aeration.

From the Los Angeles case study $\left(0.074 \mathrm{~kg} \cdot \mathrm{CO}_{2} \cdot \mathrm{eq}\right)$, the secondary treatment (activated sludge and secondary clarifier) and tertiary treatment are the most significant contributors to Greenhouse Gas emissions (GHG) (52\%). However, the sludge handling attains the lowest share $(-57 \%)$ in this impact category for all four wastewater treatment alternatives because in the facility methane is captured from anaerobic digestion and is used to generate electricity onsite, which offsets purchased electricity from alternate sources, thereby reducing operational impacts relative to other subsystems. The case study utility's gas recovery program captures essentially all their methane and prevents these emissions from being a more significant contributor. If methane emissions were not captured, the GHG results for this activity would increase 25 times [28]. 
Phoenix shows a particular behavior in global warming category, in this case, the sludge handling represents by itself more than $70 \%$ of emissions, the rest of the subsystems contribute little to the case study results, like Figure 5 shows. The amount of greenhouse gases produced from this subsystem is related with the sludge digestion and the production of methane from the anaerobic decomposition of sludge. In addition, the inexistence of an electricity recovery program, and therefore, the gas produced then flared and vented increase exponentially the environmental effects in global warming category.

In the case of Iztapalapa $\left(0.596 \mathrm{~kg} \cdot \mathrm{CO}_{2} \cdot \mathrm{eq}\right)$ the activated sludge system presented the highest environmental burden in the global warming category (53\%), when compared to the other systems, due to the high energy input for aeration.

\subsubsection{Eutrophication}

Eutrophication was evaluated using the baseline method described in CML-IA methodology is defined for the midpoint approach [37], which is based on generic eutrophication potential (EP) factors. Results are given in $\mathrm{kg} \mathrm{PO}_{4}^{-}$equivalent per FU $\left(1 \mathrm{~m}^{3}\right)$, where WWTP Iztapalapa has an impact of 1.069 , the biggest of the facilities compared to the 0.43 in Na and 0.0084 in Phoenix and Los Angeles. The impacts of Naucalpan and Iztapalapa are due to the bad practices in the Biosolids handling, such as the discharges to the water bodies (water disposal subsystem) which totally determine the impact on eutrophication. Despite the fact that the WWTP Naucalpan and Iztapalapa were not designed for phosphorus removal, eutrophication arising from emissions of nitrogen to water was included in the initial assessment. Los Angeles and Phoenix showed the most favorable results for eutrophication potential due to the strict laws for water disposal into water bodies, having a care in the removal of nutrients.

The detailed analysis performance show that two substances were found to account for more than $90 \%$ of the total value of the impact category, ammonium and phosphorus, which agrees with Hospido et al. [36], where she reported that ammonia and phosphorus are the two main substances that impact eutrophication category.

\subsubsection{Ozone Layer Depletion}

The ozone layer depletion potential is superior for Iztapalapa $(0.0000001581$ g.CFC- ${ }_{11}$ eq) than for Naucalpan $\left(0.0000000322\right.$ g.CFC- ${ }_{11}$ eq $)$, Los Angeles $\left(0.0000001131 \mathrm{~g} \cdot \mathrm{CFC}_{-11}\right.$.eq) and Phoenix $\left(0.0000000901 \mathrm{~g} \cdot \mathrm{CFC}_{11}\right.$ eq), due to the consume of electricity for pumping and aeration in the facilities and the diesel used in the transportation of the sludge and wastes for final disposal.

\subsubsection{Human Toxicity}

The impact category of human toxicity is higher for Naucalpan $(0.738774$ $\mathrm{kg} \cdot 1,4-\mathrm{DB} \cdot \mathrm{eq})$ than for Los Angeles (0.449079 kg.1,4-DB·eq), Phoenix (0.412274 $\mathrm{kg} \cdot 1,4-\mathrm{DB} \cdot \mathrm{eq})$ and Iztapalapa (0.212998 kg-1,4-DB·eq). This is because the heavy metals in the sludge (Naucalpan and Iztapalapa), this is due low capacity for removing heavy metals in addition with the high concentration of the samples 
analyzed during the data collection, the diesel used in the transportation of the sludge in the case of Los Angeles and Phoenix is also a contributor of human toxicity, which agree with Hospido et al. [36]. In this sense, the amount of sludge at the WWTPs is dependent on two opposite aspects: the implementation of secondary treatment and anaerobic digestion. If this occurs, a higher production takes place. And if it happens, a great reduction of sludge is achieved. Iztapalapa and Naucalpan combines both aspects in a negative direction (presence of secondary treatment and absence of anaerobic digestion) so a huge amount of sludge is produced (see Table 1) and an extremely high impact is brought about (Figure 4). On the contrary, Los Angeles and Phoenix merges both effects in a positive sense (absence of secondary treatment and presence of anaerobic digestion), which explains the minor value attained for this impact category (Figure $5)$.

\subsubsection{Photochemical Oxidation}

The Photochemical oxidation category was chosen according to Lundie et al. [24] that listed PO as one of the categories of relevance to the water industry. In addition Rodriguez-Garcia et al. [38] present that $12 \mathrm{~g}$ of ethane equivalents are emitted per person equivalent when using a conventional system for wastewater treatment. The values presented here are far higher, being the higher Phoenix with $0.000839 \mathrm{~g}$ per fu, Naucalpan $(0.000284 \mathrm{~g})$ Iztapalapa $(0.000117 \mathrm{~g})$ and Los Angeles with $0.000018 \mathrm{~g}$, as a result of a more significant energy use (direct and indirect) and diesel for transportation, elements that dominates the emissions associated with this impact category.

\subsection{Economic Assessment}

\subsubsection{Capital Costs}

The costs calculated for the WWTF are shown in Table 3. The results of the costs analysis show that $\mathrm{Na}$ facility $(22 \mathrm{~L} / \mathrm{s})$ is the most economical in terms of capital costs $\left(79,732 \mathrm{USD} / \mathrm{m}^{3}\right)$, followed by Iz $(1500 \mathrm{~L} / \mathrm{s})$, while $\mathrm{La}(3000 \mathrm{~L} / \mathrm{s})$ and $\mathrm{Ph}(1400 \mathrm{~L} / \mathrm{s})$ clearly had the greatest costsper cubic meter of treated wastewater $18,368,000 \mathrm{USD} / \mathrm{m}^{3}$ and $21,648,000 \mathrm{USD} / \mathrm{m}^{3}$, respectively. These findings would indicate that the capital costs of the WWTF increase as the flow increase for each $\mathrm{L} / \mathrm{s}$ of capacity of flow, however there is fluctuation among facilities, which is due to materials, equipment, and the civil works at the time of estimating the budget, which ostensibly affects the value calculated in comparison between USA and Mexico facilities. For the USA facilities, the investment costs are assumed indirectly by the inhabitants of the population benefited, through the financing by national government, while in Mexico WWTF the capital costs are not shown as a benefit or investment for inhabitants.

\subsubsection{0\&M Costs}

Due to scale effect of having wastewater treatment capacity of $3000 \mathrm{~L} / \mathrm{s}$ and 1400 $\mathrm{L} / \mathrm{s}$, La and $\mathrm{Ph}$ facilities have the lowest total economic cost per cubic meter of treated water. While Iz and Na presented the highest cost per cubic meter of 


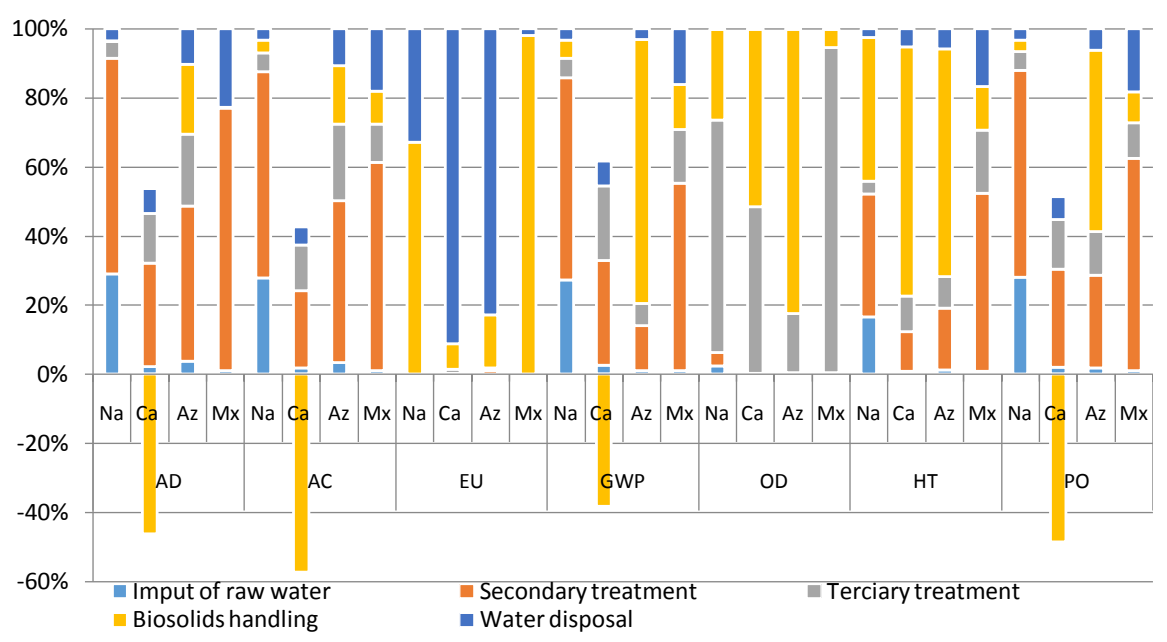

Figure 5. Analysis of contribution per subsystem for the global warming.

Table 3. Capital cost and O\&M cost of facilities evaluated.

\begin{tabular}{cccccc}
\hline Indicator & Units & Naucalpan & Los Ángeles & Phoenix & Iztapalapa \\
\hline Capital costs & USD $\$ \mathrm{~m}^{3}$ & $79,732,653.18$ & $18,368,682.29$ & $21,648,804.13$ & $13,745,008.67$ \\
O\&M costs & USD $\$ \mathrm{~m}^{3}$ & 0.60910489 & 0.055 & 0.09109 & 0.109555275 \\
\hline
\end{tabular}

treated water. From and operation and maintenance $(\mathrm{O} \& M)$ costs, the electricity consumption for pumping and labor costs are the two the principal contributors to the O\&M costs.

Since there is no difference of technologies (all four-facilities present activated sludge as main processes) that affect the average consumption energy per cubic meter, the main variation among facilities is the potential to produce electricity by anaerobic digestion of sludge and then use it in the same facilities, this reduce significantly the grid electricity consumption and thus the cost of electricity in the wastewater treatment.

In general, labor cost, due disparity of salaries between Mexico and USA, are much larger in $\mathrm{La}$ and $\mathrm{Ph}$ facilities, however due the mechanization of technologies fewer personal is required in $\mathrm{Ph}$ and $\mathrm{La}$ than $\mathrm{Na}$ and Iz. Thus, to decrease labor cost by improving management and save energy consumption by upgrading the treatment equipment will be effective alternatives to lower economic cost of wastewater treatment facilities in Mexico.

The economic costs of sludge disposal covered a very little proportion of O\& $M$ cost of four wastewater treatment facilities, which means that very little money was used in it. Thus, most of the sludge was disposed of simple landfill, which represents the present situation of sludge disposal in wastewater treatment process in USA.

\subsection{Summarized Sustainability Indicators}

The evaluation of sustainability under a life cycle approach applied to 4 WWTF considered the application of twelve indicators, seven environmental, three so- 
cial and two economic. To present the results of environmental LCA and economic evaluation in a combined and visual tool, a three-degree scale was used, the scale proposed is based on the performance assessment of each indicator, where the best performance is given the "best option", then "intermediate" and the worst performance received the term "worst option". Nevertheless, this scale is just illustrative and does not normalize, judge or weight impact categories, and no discussion about interpretations are presented. Moreover, Figure 6 is only an easy way to visualize the environmental and economic results, and it does not pretend to connect indicators or their influence each other neither to score the results.

As reported in Table 4 and Figure 6, La facility was the best option in ten of twelve categories evaluated, followed by $\mathrm{Ph}$ which overall score was intermediate and the worst facility was given to $\mathrm{Na}$ for the low performance in six of nine indicators.

For the environmental dimension, La was the best evaluated in five of seven categories evaluated (AD, AI, EI, OD, POI) only GW and HTI presented an "intermediate performance". The performance results for $\mathrm{Ph}$ facility were below La, in this case only EI category obtained "best option" qualification, the rest seven indicators were classified as "intermediate option". Iz facility presented the same order of magnitude due to three indicators obtained "intermediate option" (AD, AI and POI) while GW and HTI received the term "best option", only EI and OD were referenced as "worst option". The overall worst performance (worst option) was for $\mathrm{Na}$ in three categories (AD, AI and HTI) the rest of indicators were classified as intermediate option.

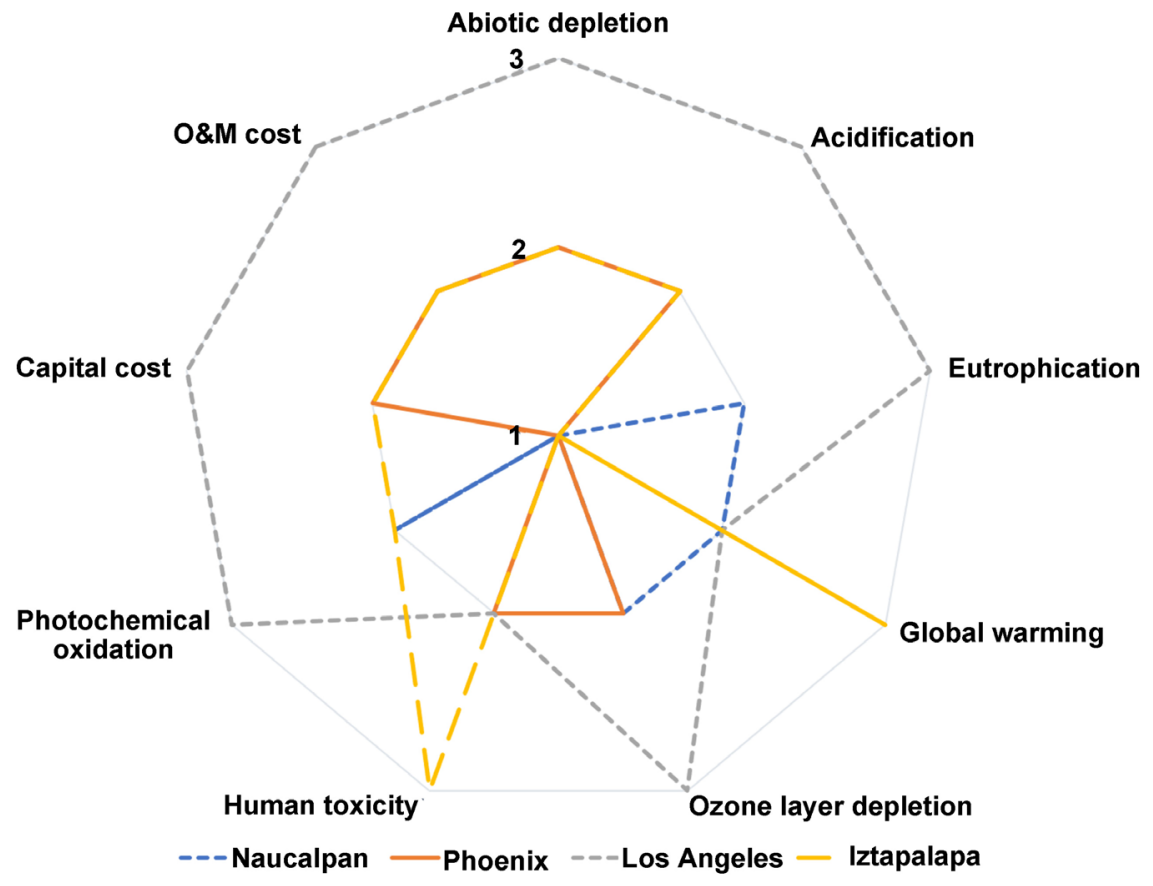

Figure 6. Sustainability scores of the total wastewater treatment facilities evaluated under three-scale performance (1: worst option, 2: intermediate and 3: best option). 
Table 4. Life cycle sustainability indicators evaluated in the four WWTF.

\begin{tabular}{|c|c|c|c|c|c|}
\hline \multirow{2}{*}{ Dimension } & \multirow{2}{*}{ Indicator } & \multicolumn{4}{|c|}{ WWTF } \\
\hline & & $\mathrm{Na}$ & $\mathrm{Ph}$ & $\mathrm{La}$ & $\mathrm{Iz}$ \\
\hline \multirow{7}{*}{ Environmental } & $\mathrm{AD} \mathrm{MJ}$ & 16.36 & 7.25 & 0.366 & 5.03 \\
\hline & $\mathrm{AI}\left(\mathrm{g} \cdot \mathrm{SO}_{2} \cdot \mathrm{eq}\right)$ & 0.0109 & 0.004868 & -0.000579 & 0.00407 \\
\hline & $\mathrm{EI}\left(\mathrm{g} \cdot \mathrm{PO}_{4} \cdot \mathrm{eq}\right)$ & 0.43 & 0.0084 & 0.0084 & 1.069 \\
\hline & $\mathrm{GW}\left(\mathrm{g} \cdot \mathrm{CO}_{2} \cdot \mathrm{eq}\right)$ & 1.47 & 2.21 & 0.073 & 0.60 \\
\hline & $\mathrm{OD}\left(\mathrm{g} \cdot \mathrm{CFC}-_{11} \cdot \mathrm{eq}\right)$ & 0.0000000322 & 0.0000000901 & 0.0000001131 & 0.0000001581 \\
\hline & HTI (g.1,4-DB·eq) & 0.738774 & 0.412274 & 0.449079 & 0.212998 \\
\hline & POI $\left(\mathrm{g} \cdot \mathrm{C}_{2} \mathrm{H}_{4}\right)$ & 0.000284 & 0.000839 & 0.000018 & 0.000117 \\
\hline \multirow{2}{*}{ Economic } & $\begin{array}{l}\text { Capital costs } \\
\left(\mathrm{USD} \$ \mathrm{~m}^{3}\right)\end{array}$ & $79,732,653.18$ & $21,648,804.13$ & $18,368,682.29$ & $13,745,008.67$ \\
\hline & $\begin{array}{l}\mathrm{O} \& \mathrm{M} \cdot \text { costs } \\
\left(\mathrm{USD} \$ \mathrm{~m}^{3}\right)\end{array}$ & 0.60910489 & 0.09109 & 0.055 & 0.109555275 \\
\hline Table caption & & Worst option & $\begin{array}{l}\text { Intermediate } \\
\text { option }\end{array}$ & Best option & $\begin{array}{l}\text { Intermediate } \\
\text { option }\end{array}$ \\
\hline
\end{tabular}

Regarding economic evaluation, even though the labor costs and energy price for the operation of facilities in USA were higher than Mexico, the overall costs, related to civil works, waste management, capital cost, etc, were lower (USD/m $\mathrm{m}^{3}$ ) for $\mathrm{Ph}$ and La. It was found that larger the treatment capacity, the lower the O\&M costs of wastewater treatment was. The difference of treatment technologies for co-generation affect the unit energy cost of wastewater treatment.

The overall performance obtained, based on both, environmental and economic assessment is as following (from best to worst):

- Los Angeles.

- Arizona.

- Iztapalapa.

- Naucalpan.

\section{Conclusions}

During this research, a sustainability framework was proposed using life cycle approach for selecting the best sustainable technology by considering economic and environmental aspects. The integration of environmental and economic assessment results in an important feature of sustainability assessment of wastewater since it makes visible the identification of strengths and weaknesses of the facilities.

In the present study, the WWTP Ca attained the most favorable results from an environmental perspective in most of the categories assessed. Within eutrophication impact category, the discharge to the environment of untreated ammonium and phosphorous was identified as the main contributor and, in this sense, we need to consider better actions in the nitrogen and/or phosphate re- 
moval in the design of WWTPs.

The WWTP Ca alternative allows the opportunity for heat and energy recovery which can offset fossil fuel consumption and prevent GHG emissions, reducing environmental effects. For the utility, the plant produces approximately $90 \%$ of its electricity need using captured methane. If the facility is compared by itself, the GHG emissions are negative, compared to other facilities. It should be noted that the case study utility augments its negative impacts if energy recovery should not be conducted in site. In particular, the aeration subsystem would contribute the increase of global warming factor.

Sludge disposal choices also allow utility to control some of their life-cycle environmental effects. Disposal choices reduce environmental burden because offsets of fuel or electricity consumption or other materials (e.g., fertilizers) can reduce the utility's overall environmental footprint.

Regarding to the facility in Arizona, the electricity consumption, principal contributor to the environmental impacts, could be reduced if an electricity recovery plant, which it means savings of 2000 MWh per annum and carbon footprint reduction of 1400 metric tons, is installed within the current facility. In addition, if biogas is produced, the recovery of the energy content can be possible to minimize all the impacts where the electricity consumption is the contributor of the impacts. So, attention to this should be paid in addition to the energy consumption associated.

The results suggest that the installation of one big WWTP is better, in environmental terms that small WWTP for most of the impact categories analyzed. However, in order to extrapolate the results obtained to other locations, special attention should be taken to wastewater transport, electricity mix and sludge management. The digestion of the sludge also entails several benefits as the sludge is partially stabilized and the volume significantly reduced.

The inclusion of economic aspects, in our study, only the real money flows related to the wastewater were considered, as we could not identify external costs that are likely to be included in the near future. In future works, other perspectives for the Life Cycle Costing analysis of wastewater could be used, for instance, the perspective of the society where the wastewater are applied, and deeper efforts should be devoted assuring the non-existence of external costs likely to be included soon.

Future research is needed to apply and further develop the approach with respect to its conceptual robustness (set of sustainability principles and assessment methodology) and its applicability in participatory and collaborative water modeling and other social indicators. Providing a process for, and results from, sustainability assessments of future scenarios leaves room for transparency, criticism and discussion regarding sustainable development in the process of sustainability water resources.

\section{Conflicts of Interest}

The authors declare no conflicts of interest regarding the publication of this paper. 


\section{References}

[1] Morrison, M., Srinivasan, R.S. and Ries, R. (2016) Complementary Life Cycle Assessment of Wastewater Treatment Plants: An Integrated Approach to Comprehensive Upstream and Downstream Impact Assessments and Its Extension to Building-Level Wastewater Generation. Sustainable Cities and Society, 23, 37-49. https://doi.org/10.1016/j.scs.2016.02.013

[2] Comisión Mundial sobre Medio Ambiente y Desarrollo (1987) Preserving Our World: A Consumer's Guide to the Brundtland Report. 135.

[3] Pope, J., Bond, A., Hugé, J. and Morrison-Saunders, A. (2017) Reconceptualising Sustainability Assessment. Environmental Impact Assessment, 62, 205-215.

[4] Finkbeiner, M., Schau, E.M., Lehmann, A. and Traverso, M. (2010) Towards Life Cycle Sustainability Assessment. Sustainability, 2, 3309-3322.

https://doi.org/10.3390/su2103309

[5] Martínez-Blanco, J., et al. (2014) Application Challenges for the Social Life Cycle Assessment of fertilizers within Life Cycle Sustainability Assessment. Journal of Cleaner Production, 69, 34-48. https://doi.org/10.1016/j.jclepro.2014.01.044

[6] International Organization for Standardization (2006) ISO 14040-Environmental Management-Life Cycle Assessment-Principles and Framework. International Organization for Standardization, Vol. 3, 20.

[7] Graae, J., Keithley, S., Luc, M. and Pawl, J. (1998) Alternative Solutions for Wastewater Treatment in U.S.-Mexico Border Colonias: An Analysis from Socio-Economic and Technological Perspectives. University of California at Santa Barbara.

[8] Hidalgo, D., Irusta, R., Martinez, L., Fatta, D. and Papadopoulos, A. (2007) Development of a Multi-Function Software Decision Support Tool for the Promotion of the Safe Reuse of Treated Urban Wastewater. Desalination, 215, 90-103. https://doi.org/10.1016/j.desal.2006.09.028

[9] Muga, H.E. and Mihelcic, J.R. (2008) Sustainability of Wastewater Treatment Technologies. Journal of Environmental Management, 88, 437-447. https://doi.org/10.1016/j.jenvman.2007.03.008

[10] Imteaz, M.A., Ahsan, A., Naser, J. and Rahman, A. (2011) Reliability Analysis of Rainwater Tanks in Melbourne Using Daily Water Balance Model. Resources, Conservation and Recycling, 56, 80-86. https://doi.org/10.1016/j.resconrec.2011.09.008

[11] Gómez-López, M.D., Bayo, J., García-Cascales, M.S. and Angosto, J.M. (2009) Decision Support in Disinfection Technologies for Treated Wastewater Reuse. Journal of Cleaner Production, 17, 1504-1511. https://doi.org/10.1016/j.jclepro.2009.06.008

[12] Pahl-Wostl, C., Lebel, L., Knieper, C. and Nikitina, E. (2012) From Applying Panaceas to Mastering Complexity: Toward Adaptive Water Governance in River Basins.

[13] Halog, A. and Manik, Y. (2011) Advancing Integrated Systems Modelling Framework for Life Cycle Sustainability Assessment. Sustainability, 3, 469-499. https://doi.org/10.3390/su3020469

[14] United Nations Environment Programme (UNEP) (2009) Guidelines for Social Life Cycle Assessment of Products.

[15] Heijungs, R., Huppes, G. and Guinée, J.B. (2010) Life Cycle Assessment and Sustainability Analysis of Products, Materials and Technologies. Toward a Scientific Framework for Sustainability Life Cycle Analysis. Polymer Degradation and Stability, 95, 422-428. https://doi.org/10.1016/j.polymdegradstab.2009.11.010

[16] Corominas, L., et al. (2013) Life Cycle Assessment Applied to Wastewater Treatment: State of the Art. Water Research, 47, 5480-5492. 
https://doi.org/10.1016/j.watres.2013.06.049

[17] Brown, S., Beecher, N. and Carpenter, A. (2010) Calculator Tool for Determining Greenhouse Gas Emissions for Biosolids Processing and End Use. Environmental Science \& Technology, 44, 9509-9515. https://doi.org/10.1021/es101210k

[18] Weiss, P., Eveborn, D., Kärrman, E. and Gustafsson, J.P. (2008) Environmental Systems Analysis of Four On-Site Wastewater Treatment Options. Resources, Conservation and Recycling, 52, 1153-1161. https://doi.org/10.1016/j.resconrec.2008.06.004

[19] Jonsson, L. and Hellström, D. (2006) Evaluation of Small On-Site Wastewater Treatment Systems. Management of Environmental Quality: An International Journal, 17, 728-739. https://doi.org/10.1108/14777830610702548

[20] Sawyer and Hazen (2015) Florida Onsite Sewage Nitrogen Reduction Strategies Study.

[21] Muradov, N., Smith, F. and T-Raissi, A. (2008) Hydrogen Production by Catalytic Processing of Renewable Methane-Rich Gases. International Journal of Hydrogen Energy, 33, 2023-2035. https://doi.org/10.1016/j.ijhydene.2008.02.026

[22] Fernández-Sánchez, G., Berzosa, Á., Barandica, J.M., Cornejo, E. and Serrano, J.M. (2015) Opportunities for GHG Emissions Reduction in Road Projects: A Comparative Evaluation of Emissions Scenarios Using $\mathrm{CO}_{2}$ NSTRUCT. Journal of Cleaner Production, 104, 156-167. https://doi.org/10.1016/j.jclepro.2015.05.032

[23] Noyola, A., Padilla-Rivera, A., Morgan-Sagastume, J.M., Güereca, L.P. and Hernández-Padilla, F. (2012) Typology of Municipal Wastewater Treatment Technologies in Latin America. Clean Soil, Air, Water, 40, 926-932. https://doi.org/10.1002/clen.201100707

[24] Lundie, S., Peters, G.M. and Beavis, P.C. (2004) Life Cycle Assessment for Sustainable Metropolitan Water Systems Planning. Environmental Science \& Technology, 38, 3465-3473. https://doi.org/10.1021/es034206m

[25] Lassaux, S., Renzoni, R., Germain, A., Lassaux, S., Renzoni, R. and Germain, A. (2007) LCA Case Studies Life Cycle Assessment of Water from the Pumping Station to the Wastewater Treatment Plant. The International Journal of Life Cycle Assessment, 12, 118-126. https://doi.org/10.1065/lca2005.12.243

[26] Tillman, A.-M., Svingby, M. and Lundström, H. (1998) Life Cycle Assessment of Municipal Waste Water Systems. The International Journal of Life Cycle Assessment, 3, 145-157. https://doi.org/10.1007/BF02978823

[27] Yépez-García, R.A., Johnson, T.M. and Andrés, L.A. (2011) Meeting the Balance of Electricity Supply and Demand in Latin America and the Caribbean. The World Bank, Washington DC.

[28] Stokes, J.R. and Horvath, A. (2010) Supply-Chain Environmental Effects of Wastewater Utilities. Environmental Research Letters, 5, 14015-14017. https://doi.org/10.1088/1748-9326/5/1/014015

[29] Zang, Y., Li, Y., Wang, C., Zhang, W. and Xiong, W. (2015) Towards More Accurate Life Cycle Assessment of Biological Wastewater Treatment Plants: A Review. Journal of Cleaner Production, 107, 676-692. https://doi.org/10.1016/j.jclepro.2015.05.060

[30] Wernet, G., Bauer, C., Steubing, B., Reinhard, J., Moreno-Ruiz, E. and Weidema, B. (2016) The Ecoinvent Database Version 3 (Part I): Overview and Methodology. The International Journal of Life Cycle Assessment, 21, 1218-1230. https://doi.org/10.1007/s11367-016-1087-8

[31] Liu, Y., et al. (2015) Correlations between Urbanization and Vegetation Degrada- 
tion across the World's Metropolises Using DMSP/OLS Nighttime Light Data. Remote Sensing, 7, 2067-2088. https://doi.org/10.3390/rs70202067

[32] Hunkeler, D.J., Lichtenvort, K., Rebitzer, G., Ciroth, A., SETAC-Europe (2008) Environmental Life Cycle Costing. SETAC.

[33] Matos, R., Cardoso, A., Duarte, P., Ashley, R., Molinari, A. and Schulz, A. (2003) Performance Indicators for Wastewater Services-Towards a Manual of Best Practice. Water Science and Technology: Water Supply, 3, 365-371.

[34] Sadr, S.M.K., Saroj, D.P., Kouchaki, S., Ilemobade, A.A. and Ouki, S.K. (2015) A Group Decision-Making Tool for the Application of Membrane Technologies in Different Water Reuse Scenarios. Journal of Environmental Management, 156, 97-108. https://doi.org/10.1016/j.jenvman.2015.02.047

[35] Lim, S.-R., Park, D. and Park, J.M. (2008) Environmental and Economic Feasibility Study of a Total Wastewater Treatment Network System. Journal of Environmental Management, 88, 564-575. https://doi.org/10.1016/j.jenvman.2007.03.022

[36] Hospido, A., Moreira, M.T. and Feijoo, G. (2008) A Comparison of Municipal Wastewater Treatment Plants for Big Centres of Population in Galicia (Spain). The International Journal of Life Cycle Assessment, 13, 57-64. https://doi.org/10.1065/lca2007.03.314

[37] Leiden, U. (2016) CML-IA Characterisation Factors. https://www.universiteitleiden.nl/en/research/research-output/science/cml-ia-chara cterisation-factors

[38] Rodriguez-Garcia, G., Molinos-Senante, M., Hospido, A., Hernández-Sancho, F., Moreira, M.T. and Feijoo, G. (2011) Environmental and Economic Profile of Six Typologies of Wastewater Treatment Plants. Water Research, 45, 5997-6010. https://doi.org/10.1016/j.watres.2011.08.053 